AKRUAL 1 (1) (2009): 78-88 $e$-ISSN: 2502-6380

\title{
AKRUAL
}

Jurnal Akuntansi

http://fe.unesa.ac.id/ojs/index.php/akrl

\section{PERANAN ANGGARAN PARTISIPATIF DALAM RANGKA PENINGKATAN KINERJA MANAJERIAL DIKAITKAN DENGAN \\ BUDAYA ORGANISASI DAN HUBUNGAN ANTARINDIVIDU PADA ORGANISASI}

\author{
Novita Ekasari \\ Universitas Widya Kartika \\ E-mail: nesya_78@yahoo.com \\ Lintang Venusita \\ Universitas Negeri Surabaya \\ E-mail: lvenusita@yahoo.com
}

Artikel diterima: 4 Agustus 2010

Revisi terakhir: 23 September 2010

\begin{abstract}
This article aims to provide a framework to think about the role of participatory budgeting to improve managerial performance is associated with organizational culture and relationship between individuals at nonprofit organizations. Participatory budgeting process to function properly and implemented well, if supported by the device work, human resources, individual relationships within the organization, and culture that has taken hold in a nonprofit organization. Each nonprofit organization aims to improve services and performance-oriented but not profit. Several nonprofit organizations have undergone repositioning and development organization which aims other than to provide services to the community also increases the profits from service operations.
\end{abstract}

Keywords: participatory budgeting, nonprofit organization, organizational culture, relationship between individual.

\section{PENDAHULUAN}

Anggaran disusun sebagai rencana yang dituangkan dalam bentuk angka yang mencerminkan kegiatan atau program kerja suatu organisasi. Biasanya anggaran dinyatakan dalam satuan moneter dan mencakup periode tertentu. Secara umum, proses penyusunan penganggaran dalam suatu organisasi melibatkan orang-orang yang ada di dalam perusahaan. Penyusunan anggaran melibatkan aspek keuangan maupun aspek non keuangan dari kegiatan atau program kerja yang direncanakan. 
Proses penyusunan anggaran meliputi alokasi sumber daya yang dimiliki suatu organisasi, mengoordinasi kegiatan organisasi, mengidentifikasi hambatan dan keterbatasan kegiatan, mendasari setiap kegiatan dan megarahkan pelaksanaan kegiatan, serta menjadi kriteria dalam evaluasi kerja organisasi.

Organisasi nirlaba atau organisasi nonprofit merupakan organisasi yang bertujuan untuk memberikan pelayanan publik tanpa memerhatikan hal-hal yang bersifat mencari laba. Beberapa organisasi nirlaba antara lain: gereja, sekolah, rumah sakit, organisasi jasa sukarela, organisasi politis, serikat buruh, assosiasi profesional, institusi riset, dan instansi pemerintah. Di Indonesia, banyak tumbuh organisasi nirlaba terutama di bidang keagamaan, pendidikan, dan organisasi politik dan asosiasi profesi. Pengelolaan organisasi tidak hanya didasarkan pada pengukuran kinerja organisasi nirlaba saja. Meskipun organisasi nirlaba tidak berorientasi pada laba atau profit, organisasi nirlaba tetap melakukan penyusunan anggaran atas semua kegiatan organisasi tersebut.

Anggaran partisipatif merupakan anggaran yang disusun dengan melibatkan orang-orang yang berkepentingan terhadap anggaran termasuk karyawan level bawah dalam proses penyusunan anggaran. Anggaran partisipatif merupakan anggaran yang paling komunikatif karena melibatkan pendapat dan usulan dari bawahan sebelum diputuskan oleh atasan sebuah organisasi. Tidak semua organisasi menerapkan anggaran partisipatif, hal ini berkaitan dengan budaya organisasi, hubungan antar individu dalam organisasi, maupun kebijakan yang diterapkan oleh pimpinan. Penerapan anggaran partisipatif sebuah organisasi nirlaba tergantung pada komitmen orang-orang dalam sebuah organisasi untuk melaksanakan anggaran dan tidak mengabaikan budaya organisasi serta hubungan antar individu dalam organisasi tersebut. Proses penganggaran organisasi nirlaba diawali dengan penyusunan rancangan anggaran yang diusulkan dari masing-masing unit kerja, kemudian diajukan kepada pimpinan organisasi untuk mendapatkan pengesahan. Sering kali penyusunan anggaran mengalami kendala manakala usulan anggaran yang disusun oleh unit kerja tidak disetujui oleh pimpinan karena dianggap tidak sesuai dengan kondisi organisasi sehingga sering kali terjadi slack anggaran. Untuk menghindari slack anggaran pada penyusunan anggaran partisipatif, diperlukan perencanaan dan penyusunan strategi awal organisasi dengan mengombinasikan budaya organisasi serta hubungan individu dalam organisasi tersebut. Penelitian ini bertujuan untuk memberikan kerangka berpikir tentang peranan penyusunan anggaran partisipatif untuk meningkatkan kinerja manajerial dikaitkan dengan budaya organisasi dan hubungan antar individu pada organisasi nirlaba.

\section{KAJIAN PUSTAKA \\ Budaya Organisasi}

Setiap organisasi pasti memiliki budaya. Beberapa ahli mengatakan bahwa budaya sebenarnya merupakan konsep yang dipinjam oleh para pakar teori organisasi dari disiplin ilmu antropologi (Luthans, 1988). Harvey (1996: 333-334) mengemukakan bahwa budaya organisasi terdiri dari: nilai-nilai, kepercayaan, bentuk perilaku dari 
anggotanya pada suatu organisasi tertentu. Budaya organisasi mengarah pada suatu sistem nilai bersama yang dipegang oleh anggotanya yang membedakan suatu organisasi dengan organisasi yang lainnya. Karakteristik budaya organisasi adalah:

1 Otonomi individu: persetujuan mengenai tanggung jawab, kebebasan, dan kesempatan untuk berinisiatif bagi anggota organisasi;

2 Struktur: persetujuan mengenai aturan, perubahan peraturan, kuantitas penggunaan langsung supervisi untuk mengontrol perilaku anggota;

3 Pemberian insentif: persetujuan dalam pemberian insentif (misalnya kenaikan gaji, promosi) yang didasarkan atas prestasi anggota;

4 Perilaku yang merugikan: persetujuan bahwa anggota didorong untuk agresif, inovatif, dan pencarian yang penuh risiko.

\section{Dimensi/ Tingkatan Budaya dalam Organisasi}

Dimensi budaya dalam organisasi menurut Indrapraja (1992) yaitu:

1. Dimensi Pertama: Artifak-artifak (Artifacts)

Artifak (artifacts) adalah "benda-benda" hasil buatan manusia. Kita dapat mengamati suatu budaya dalam artifak yang diciptakannya berupa kata-kata yang digunakan, tindakan para anggota organisasi dan objek yang ada dalam organisasi. Apa yang dimaksudkan dengan "kata-kata budaya" di sini termasuk bahasa khusus atau jargon yang digunakan oleh orang-orang dalam organisasi, kisah-kisah yang diceritakan oleh mereka dan mitos-mitos yang dilestarikan oleh mereka. Apa yang dimaksudkan dengan "tindakan-tindakan budaya" adalah upacara ritual (ritual and ceremonies) yang diselengarakan dan diikuti oleh mereka, misalnya upacara bendera, rapan rutin harian, expose dan bentuk penyajian lain, pemberian persetujuan rapat pimpinan secara berkala, rapat kerja pimpinan cabang, rapat direksi, upacara pemberian penghargaan, malam silaturahmi, perayaan hari besar, karyawan, dan sebagainya. Sedangkan "objek budaya" di sini termasuk busana yang dikenakan para anggota organisasi, meubel yang digunakan dalam kantor, karya seni yang dipilih dan digunakan oleh para warga organisasi.

2. Dimensi Kedua: Perspektif (Perspectives)

Perspektif (perspectives), berada satu lapisan di bawah permukaan yang kelihatan (artifak-artifak), tetapi masih mudah untuk melihatnya. Termasuk di dalam perspektif adalah berbagai norma sosial dan peraturan yang mengatur bagaimana para warga organisasi harus berperilaku dalam situasi khusus. Adanya berbagai peraturan dan norma tersebut, para anggota organisasi tidak perlu memecahkan permasalahan sosial organisasi secara baru setiap timbul permasalahan.

3. Dimensi Ketiga: Nilai-nilai (Values)

Nilai-nilai (values) berada setingkat lebih dekat dengan inti suatu budaya organisasi. Values mencerminkan falsafah dan misi organisasi, cita-cita dari organisasi, tujuan dan standar organisasi. Para anggota organisasi menggunakan nilai-nilai ini untuk menilai (judging) orang-orang, tindakan, dan peluang serta mengambil keputusan atas nama organisasi. 


\section{Dimensi Keempat: Asumsi-Asumsi (Assumptions)}

Pada lapisan terdalam, yaitu inti budaya organisasi, terdapatlah kepercayaan para anggota organisasi yang tidak diucapkan tentang mereka sendiri dan mengenai orang lain. Asumsi budaya bersifat take for granted, sehingga pada dasarnya kita harus menjadi bagian dari budaya itu kalau kita mau mengerti. Akan tetapi kesulitannya adalah, sekali kita menjadi bagian dari budaya itu, kita tidak mengenalinya lagi karena unsur budaya organisasi sudah menjadi bagian dari pandangan dunia kita secara otomatis.

Budaya dalam suatu organisasi mempunyai pengaruh terhadap perilaku individu dalam organisasi, cara kerja, dan motivasi atasan dan bawahan untuk mencapai kinerja organisasi. Robbin (1996) mengemukakan budaya organisasi sebagai suatu persepsi bersama yang dianut oleh anggota-anggota organisasi itu dan menjadi suatu sistem dari makna bersama. Berdasarkan hasil penelitian yang berkaitan dengan budaya, ditentukan bahwa dimensi budaya mempunyai pengaruh terhadap penyusunan anggaran dalam meningkatkan kinerja manajerial. Hofstede (1984) mengemukakan empat dimensi budaya yaitu: individualisme, jarak kekuasaan, penghindaran ketidakpastian, dan tingkat maskulinitas. Individualisme merupakan kecenderungan terhadap kerangka sosial yang longgar dalam masyarakat di mana individu dianjurkan untuk menjaga diri mereka sendiri dan keluarga dekatnya. Jarak kekuasaan merupakan suatu ukuran di mana anggota dari suatu masyarakat menerima bahwa kekuasaan dalam lembaga atau organisasi tidak didistribusikan secara merata. Penghindaran ketidakpastian merupakan tingkatan di mana anggota masyarakat merasa tak nyaman dengan ketidakpastian dan ambiguitas. Perasaan ini mengarahkan mereka untuk memercayai kepastian yang menjanjikan dan untuk memelihara lembaga-lembaga yang melindungi penyesuaian. Tingkat maskulinitas berarti kecenderungan dalam masyarakat akan prestasi, kepahlawanan, ketegasan, dan keberhasilan material.

\section{Partisipasi Anggaran}

Menurut Brownell (1982) partisipasi anggaran sebagai suatu proses dalam organisasi yang melibatkan para manajer dalam penentuan tujuan anggaran yang menjadi tanggung jawabnya. Sedangkan menurut Sord dan Welsch (1995) dalam Sardjito dan Mothaher (2007) mengemukakan bahwa tingkat partisipasi yang lebih tinggi akan menghasilkan moral yang lebih baik dan inisiatif yang lebih tinggi pula. Partisipasi anggaran dapat berpengaruh pada sikap karyawan, meningkatkan kuantitas dan kualitas kerja, dan meningkatkan kerja sama di antara manajer atau pimpinan. Beberapa penelitian tentang partisipasi anggaran adalah sebagai berikut:

1 Sardjito dan Mothaher (2007) mengkaji tentang pengaruh partisipasi penyusunan anggaran terhadap kinerja aparat pemerintah daerah: budaya organisasi dan komitmen organisasi sebagai variabel moderating. Hasil penelitian menunjukkan bahwa terdapat pengaruh yang signifikan antara partisipasi penyusunan anggaran terhadap kinerja aparat pemerintah daerah. Semakin tinggi partisipasi penyusunan anggaran maka akan semakin meningkatkan kinerja aparat pemerintah daerah. 
Terdapat pengaruh yang signifikan antara variabel budaya organisasi dalam memoderasi partisipasi penyusunan anggaran dengan kinerja manajerial. Hasil ini menunjukkan semakin tinggi tinggi tingkat kesesuaian antara partisipasi penyusunan anggaran dan budaya organi-sasi yang berorientasi pada orang akan semakin tinggi kinerja aparat pemerintah daerah (kabag/ kasub). Terdapat pengaruh signifikan antara variabel komitmen organisasi dalam memoderasi partisipasi penyusunan anggaran dengan kinerja aparat pemerintah daerah.

2 Fahlikhatun (2007) juga menguji tentang interaksi informasi asimetri, budaya organisasi, dan group cohesiveness dalam hubungannya dengan partisipasi anggaran dan budgetary slack. Hasil pengujian menunjukkan bahwa partisipasi penganggaran berpengaruh positif signifikan terhadap budgetary slack. Informasi asimetri mempunyai pengaruh negatif tetapi signifikan terhadap hubungan partisipasi penganggaran dengan budgetary slack, sehingga hipotesis yang menyatakan bahwa partisipasi penganggaran berpengaruh positif terhadap budgetary slack pada informasi asimetri yang tinggi, tidak diterima (tidak didukung data). Hal ini dapat disimpulkan bahwa informasi asimetri merupakan variabel yang memoderasi pada pengaruh partisipasi penganggaran terhadap budgetary slack. Sedangkan budaya organisasi tidak mempunyai pengaruh terhadap hubungan partisipasi penganggaran dengan budgetary slack, sehingga hipotesis yang menyatakan bahwa partisipasi penganggaran berpengaruh positif terhadap budgetary slack pada budaya organisasi yang berorientasi pada orang ditolak (tidak didukung data). Hal ini dapat disim-pulkan bahwa budaya organisasi yang berorientasi pada orang bukan me-rupakan variabel yang memoderasi pada pengaruh partisipasi penganggaran terhadap budgetary slack. Group cohesiveness yang tinggi mempunyai pengaruh positif dan signifikan terhadap hubungan partisipasi penganggaran dengan budgetary slack. Group cohesiveness merupakan variabel yang memoderasi pada pengaruh partisipasi penganggaran terhadap budgetary slack.

\section{Penganggaran pada Organisasi Nirlaba}

Beberapa organisasi nirlaba seperti yayasan pendidikan, rumah sakit, organisasi politik, maupun organisasi pemerintahan mempunyai tujuan berbeda dari organisasi yang berorientasi pada laba. Organisasi nirlaba bertujuan untuk memberikan jasa secara efisien dan efektif sesuai dengan tujuan pendirian awal organisasi tersebut. Pengukuran kinerja pada organisasi nirlaba masih belum me-miliki standar yang jelas tentang layanan jasa dan ukuran kinerja yang mudah diterapkan pada organisasi nirlaba adalah pengeluaran untuk setiap kegiatan tidak boleh melebihi pengeluaran yang dianggarkan, maka anggaran induk yang ditetapkan merupakan dasar pengaturan pengeluaran aktivitas. Anggaran pada organisasi nirlaba merupakan batasan yang harus dipatuhi oleh masing-masing unit kerja. Penyusunan anggaran untuk organisasi nirlaba dimulai dengan menentukan estimasi pendapatan total dan pengeluaran untuk suatu periode anggaran tertentu. Anggaran mengharuskan suatu organisasi untuk dapat mengelola sumber-sumber pendanaan yang dimiliki dan 
mengharuskan organisasi mengatur penggunaan dana tersebut untuk melaksanakan kegiatan-kegiatan yang dijalankan oleh perusahaan.

\section{Kinerja Manajerial}

Kemampuan manajer dalam menciptakan nilai lebih bagi para stakeholder organisasi merupakan ukuran keberhasilan kinerja dalam menjalankan organisasi nirlaba. Hal ini merupakan konsekuensi bagi seorang manajer sebagai pengelola perusahaan. Kinerja organisasi nirlaba tergantung pada kinerja para karyawan dan kinerja manajer, sehingga dibutuhkan sistem pengukuran kinerja yang berfungsi untuk memberikan informasi relevan dalam rangka pengambilan keputusan strategis kepada para manajer.

Banyak organisasi yang melakukan pengukuran kinerja organisasi perusahaan hanya ditekankan pada sudut pandang keuangan, dan mengabaikan pengukuran kinerja nonkeuangan. Pengukuran kinerja nonkeuangan dipercaya dapat digunakan untuk melengkapi figur pengukuran kinerja keuangan jangka pendek dan sebagai indikator kinerja jangka panjang (Kaplan dan Norton, 1996). Organisasi nirlaba yang berorientasi pada pelayanan publik tentu tidak bertujuan untuk mengejar profit atau laba yang besar, sehingga pengukuran kinerja lebih ditekankan pada penilaian mutu kinerja pelayanan publik.

Sistem pengukuran kinerja memiliki sasaran penerapan strategi yang telah ditetapkan dan merumuskan ukuran-ukuran keberhasilan pelaksanaan strategi. Menurut Kim dan Larry (1998) sistem pengukuran kinerja adalah frekuensi pengukuran kinerja pada manajer dalam unit organisasi yang dipimpin mengenai kualitas dalam aktivitas operasional perusahaan. Adanya penerapan sistem pengukuran kinerja organisasi nirlaba diharapkan akan memengaruhi hasil kerja dari manajer yang dalam hal ini adalah kinerja manajerial. Manajer diharapkan mampu menghasilkan suatu kinerja manajerial yang tinggi. Hal ini berbeda dengan kinerja karyawan umumnya yang bersifat konkret, kinerja manajerial adalah bersifat abstrak dan kompleks (Mulyadi dan Johny, 1999).

\section{Hubungan Antarindividu dalam Suatu Organisasi Nirlaba}

Hubungan antarindividu dalam suatu organisasi dapat dilihat dari komunikasi yang terjalin antara atasan dan bawahan. Komunikasi sangat penting dalam organisasi untuk mewujudkan tujuan organisasi. Komunikasi diperlukan untuk menjalin hubungan yang harmonis dalam menyampaikan informasi dari atasan ke bawahan dan sebaliknya. Komunikasi juga diperlukan apabila atasan memberikan arahan dan perintah kepada bawahan, agar dapat diterima oleh bawahan dengan baik. Komunikasi antara bawahan dan atasan juga digunakan pada saat bawahan menyampaikan laporan atas tugas atau pekerjaan yang telah diselesaikan dan juga usulan-usulan kegiatan atau program kerja baru untuk kepentingan organisasi. Arus komunikasi dalam organisasi menurut Gumilar (2008) adalah: 
1. Komunikasi ke atas

Merupakan pesan yang dikirim dari tingkat hirarki yang lebih rendah ke tingkat yang lebih tinggi. Misal: dari ketua himpunan ke ketua bidang, atau dari ketua panitia kepada para pelaksana. Komunikasi ini sangat penting untuk mempertahankan dan bagi pertumbuhan organisasi. Muncul manajemen um-pan balik yang dapat menumbuhkan semangat kerja bagi anggota organisasi. Adanya perasaan memiliki dan merasa sebagai bagian dari organisasi dari bawahannya.

2. Komunikasi ke bawah

Merupakan pesan yang dikirim dari tingkat hirarki yang lebih tinggi ke tingkat yang lebih rendah. Contoh, pesan dari direktur pada sekretaris, dari ketua senat pada bawahannya, dan lain-lain.

3. Komunikasi lateral

Merupakan arus pesan antarsesama ketua bidang ke ketua bidang, anggota ke anggota. Pesan semacam ini bergerak di bidang yang sama dalam organisasi atau mengalir antarbagian.

4. Kabar burung

Jika tiga jenis komunikasi di atas mengikuti pola struktur formal didalam organisasi, maka yang tergolong kabar burung tidak mengikuti garis formal semacam itu. Sulit melacak sumber asli penyampai pesan.

5. Kepadatan informasi

Banyaknya informasi yang diterima sehingga timbul kesulitan untuk menentukan informasi mana yang dianggap lebih penting untuk disampaikan terlebih dahulu. Mudahnya informasi dapat diterima dan disebarkan membuat para pemberi pesan lupa bahwa informasi yang disampaikan butuh dicerna terlebih dahulu dan itu membutuhkan waktu. Apalagi informasi yang disampaikan oleh atasan lebih banyak mengenai permasalahan daripada pemecahan.

\section{PEMBAHASAN}

Budaya organisasi dan hubungan antarindividu dalam suatu organisasi nirlaba merupakan hal yang berperan dalam kesuksesan suatu kegiatan dan program kerja organisasi nirlaba. Kegiatan dan program kerja yang dijalankan organisasi nirlaba memerlukan penggunaan sumber daya financial dan nonfinancial organisasi. Pemanfaatan dan penggunaan sumber daya organisasi tersebut berkaitan dengan penyusunan anggaran organisasi. Pada beberapa organisasi nirlaba yang menerapkan anggaran partisipasi akan memudahkan mengukur kinerja karena dalam penyusunan anggaran partisipasi membutuhkan kerja sama dan peran serta dari para karyawan dan pimpinan organisasi untuk mencapai kinerja pelayanan publik yang baik.

Partisipasi bawahan dalam penyusunan anggaran sangat penting untuk pencapaian tujuan organisasi. Menurut Siegel dan Marconi (1989) menyatakan bahwa partisipasi bawahan dalam penyusunan anggaran mempunyai hubungan yang positif dengan pencapaian tujuan organisasi. Dalam penyusunan anggaran par-tisipasi, seorang bawahan mempunyai kesempatan untuk menyampaikan informasi yang diketahui kepada atasan sehingga atasan dapat memilih keputusan yang sesuai dengan 
kondisi organisasi untuk pencapaian tujuan. Adanya partisipasi bawahan akan memudahkan penyelarasan tujuan dari berbagai bagian dalam organisasi untuk mencapai tujuan secara menyeluruh. Penerapan partisipasi anggaran akan meningkatkan kebersamaan, menumbuhkan rasa memiliki organisasi dari para karyawannya, adanya kesempatan untuk menyumbangkan ide dan pemikiran untuk kemajuan organisasi, serta mengurangi terjadinya konflik antara individu baik bawahan maupun atasan. Konflik yang terjadi pada saat penyusunan anggaran dapat menimbulkan kesenjangan anggaran (budgetary slack). Kesenjangan anggaran (budgetary slack) juga dapat terjadi jika keterlibatan bawahan menyalahgunakan informasi yang diketahui bawahan untuk kepentingan pribadinya. Menurut Anthony dan Govindarajan (2001) budgetary slack mencerminkan adanya perbedaan antara jumlah anggaran yang sengaja disusun oleh manajer dengan jumlah estimasi terbaik perusahaan. Sedangkan menurut Schiff dan Lewin (1970) menyatakan bahwa bawahan menciptakan budgetary slack karena dipenga-ruhi oleh keinginan dan kepentingan pribadi sehingga akan memudahkan pencapaian target anggaran, terutama jika penilaian prestasi manajer ditentukan berdasarkan pencapaian anggaran.

Beberapa organisasi nirlaba seperti rumah sakit, yayasan pendidikan, organisasi politik telah menggunakan anggaran partisipasi. Beberapa organisasi tersebut di atas telah melibatkan para karyawan untuk mengusulkan dan memberikan informasi yang berkaitan dengan penyusunan anggaran. Karakteristik organisasi nirlaba adalah memberikan pelayanan yang baik kepada masyarakat. Namun beberapa organisasi nirlaba seperti rumah sakit mulai berorientasi pada manajemen rumah sakit yang dikelola secara ekonomis atau rumah sakit swadana di mana sebagian dana diperoleh dari pemerintah dan sebagian lagi diperoleh dari kegiatan pelayanan kesehatan sehingga rumah sakit memiliki peranan ganda yaitu pening-katan pelayanan kesehatan masyarakat dan pencapaian laba atas kegiatan operasional. Oleh karena itu rumah sakit dihadapkan pada upaya pengembangan dan peningkatan mutu untuk merespons persaingan pelayanan yang berkualitas dan pemberdayaan potensi-potensi dan sumber daya yang dimiliki. Untuk mencapai sinkronisasi tujuan tersebut, maka diperlukan pemahaman atas budaya organisasi, kerja sama dan hubungan yang kondusif antarindividu dalam organisasi rumah sakit. Berdasarkan orientasi tersebut, rumah sakit sebagai organisasi nirlaba harus menetapkan ukuran kinerja pelayanan dan ukuran profitabilitas pelayanan. Setelah perumusan tujuan dan ukuran kinerja pelayanan, maka rumah sakit dapat melakukan implementasi dalam bentuk penyusunan anggaran partisipasi untuk menjalankan kegiatan operasional. Penentuan rumusan tujuan organisasi rumah sakit merupakan sarana terbaik bagi penyesuaian diri karyawan, pelayanan pada pelanggan dalam hal ini pasien maupun pihak-pihak yang berkepentingan seperti investor, dan instansi pemerintah yang terkait dengan organisasi rumah sakit.

Anggaran partisipasi juga banyak diterapkan pada organisasi pemerintah baik pusat maupun daerah. Proses penyusunan anggaran di suatu instansi pemerintah didasarkan pada ketentuan pemerintah tentang penyusunan anggaran pendapatan dan belanja daerah (APBD). Penyusunan rancangan APBD yang dilaksanakan oleh tim 
anggaran bersama-sama unit organisasi perangkat daerah untuk diajukan ke Dewan Perwakilan Rakyat pusat maupun daerah. Rancangan anggaran unit kerja dimuat dalam suatu dokumen yang disebut dengan Rancangan Anggaran Satuan Kerja (RASK) yang menggambarkan kerangka logis hubungan antara kebijakan anggaran (arah dan kebijakan umum APBD serta strategi dan prioritas APBD) dengan operasional anggaran (program dan kegiatan anggaran) di setiap unit pelaksana anggaran daerah sesuai dengan visi, misi, tugas pokok, dan fungsi unit kerja yang bersangkutan dalam penyelenggaraan pemerintahan dan pelayanan masyarakat. RASK memuat juga standar analisa belanja, tolok ukur kinerja, dan standar biaya sebagai instrumen pokok dalam anggaran kinerja. RASK merupakan dokumen daftar usulan kegiatan dan daftar usulan proyek yang selama ini digu-nakan dalam penyusunan rancangan APBD.

Pengukuran kinerja sektor publik adalah suatu sistem yang bertujuan untuk membantu pimpinan pemerintahan dalam menilai pencapaian suatu strategi melalui alat ukur finansial dan nonfinansial. Anggaran partisipatif merupakan sarana untuk pendekatan manajerial yang dapat meningkatkan kinerja setiap karyawan organisasi sebagai individual karena dengan adanya partisipasi karyawan dalam penyusunan anggaran diharapkan setiap individu mampu meningkatkan kinerja-nya sesuai dengan target yang telah ditetapkan. Penyusunan anggaran dalam orga-nisasi pemerintah juga dipengaruhi oleh budaya organisasi, perilaku individu, cara kerja, dan motivasi para pimpinan dan bawahannya untuk mencapai kinerja organisasi. Penyusunan anggaran organisasi pemerintah juga mencerminkan kondisi para bawahan mempunyai informasi yang lebih akurat daripada para atasan-nya mengenai kondisi-kondisi lokal pusat pertanggungjawaban yang dipimpinnya, sehingga dengan penerapan anggaran partisipasi mampu mengakomodasi berbagai sumber daya yang dimiliki, tugas dan kegiatan unit kerja, dan pencapaian tujuan organisasi pemerintah. Partisipasi bawahan berdasarkan pada unit kerja yang di-pimpin merupakan aspirasi bawahan dalam penyusunan anggaran. Penyusunan anggaran dapat berjalan dengan baik apabila hubungan antarindividu dalam organisasi pemerintah baik dan budaya organisasi mendukung tujuan organisasi. Tujuan organisasi pemerintah adalah melaksanakan amanat rakyat sebagaimana yang tertuang dalam Undang-Undang Dasar 45 yaitu peningkatan kesejahteraan rakyat, sehingga setiap organisasi pemerintah harus mendasarkan kinerja pada pelayanan masyarakat dengan persetujuan dari dewan perwakilan rakyat menyu-sun dan menjalankan tujuan organisasi sesuai yang telah ditetapkan sebelumnya.

\section{SIMPULAN}

Proses penyusunan anggaran partisipasi dapat berjalan dengan baik dan diimplementasikan dengan baik, apabila didukung oleh perangkat kerja, sumber daya manusia, hubungan individu dalam organisasi, serta budaya yang telah mengakar di organisasi nirlaba. Setiap organisasi nirlaba bertujuan untuk meningkatkan pelayanan dan kinerja tetapi tidak berorientasi pada profit. Beberapa organisasi nirlaba telah 
mengalami reposisi dan pengembangan organisasi dimana selain bertujuan untuk memberikan pelayanan kepada masyarakat juga meningkatkan profit dari pelayanan operasional. 


\section{DAFTAR PUSTAKA}

Anthony, R.N dan V. Govindarajan. 2001. Management Controls Systems. Boston: Mc Graw-Hill Co.

Brownell, Peter. 1982a. The Role of Accounting Data in Performance Evaluation, Budgetary Partisipative, and Organizational Effectiveness. Journal of Accounting Research, Vol. 20, pp. $12-27$.

Falikhatun. 2007. Interaksi Informasi Asimetri, Budaya Organisasi, dan Group Cohesiveness dalam Hubungan Antara Partisipasi Anggaran dan Budgetary Slack (Studi Kasus pada Rumah Sakit Umum Daerah Se Jawa Tengah), FE UNS Surakarta.

Gumilar, Gumgum, 2008, Komunikasi \& kepemimpinan dalam Organisasi, Training Leadership Himpunan Mahasiswa Ilmu Komunikasi UNIKOM.

Harvey, Don dan Robert Bruce Bowin. 1996. Human Resource Management: An

Experiential Approach. Prentice-Hall International, Inc.

Hofstede, G. 1984 Cultural dimensions in management and planning. Asia Pacific Journal of Management January.

Indrapradja, F.X.T. 1992. Manajemen Konsensus dalam Bisnis. Jurnal Ilmu-Ilmu Sosial. Vol. 3. Jakarta: Gramedia Pustaka Utama.

Kaplan, R.S. and Norton, D.P. 1996. Translating strategy into action: the balanced scorecard. Boston, Harvard Business School Press.

Kim, L and Larry, N 1998."Performance effect of complementarities between manufacturing practice and management accounting system". Journal of management accounting research. Volume 10: pp. 325-346.

Luthans, F. 1988 Organizational Behavior. Mc.Graw Hill Co.

Mulyadi. and Johny. 1999,"Sistem Perencanaan dan Pengendalian Manajemen: SistemPelipat Ganda Kinerja Perusahaan”. Edisi I, Aditya Media, Yogyakarta. Hal. 214.

Robbins, S.P. 1996 Perilaku Organisasi: Konsep, Kontroversi, Aplikasi. Prenhallindo, Jakarta.

Sardjito dan Muthaher, 2007, Pengaruh Partisipasi Penyusunan Anggaran Terhadap Kinerja Aparat Pemerintah Daerah: Budaya Oganisasi dan KOmitmen Organisasi Sebagai Variabel Moderating, Universitas Islam Sultan Agung.

Schieff, M., dan A. Y. Lewin, 1970. "The Impact of People Budgets". The Accounting Review 45. April pp. 259 - 268.

Siegel, G., dan H.R. Marconi, 1989. Behavioral Accounting. South Western Publishing, Co. Cincinnati, OH. 